\title{
Interspecies Crosses: Aspects of Animal Protection
}

\author{
A position statement of the Ethics Committee for Animal Studies ${ }^{1}$ of the Swiss Academy of Medical \\ Sciences (SAMS) and the Swiss Academy of Sciences (SCNAT)
}

\section{Introduction}

In biological-medical research and in particular in stem cell research, cross-species consisting of the cells and genetic material of animals and humans are generated for various purposes. What is involved here is the testing of the development potential of stem cells (i.e. body cells that can differentiate into different cell types or tissue) and possible xenotransplantation applications (i.e. removal of animal organs, tissue or cells and their transfer to human patients). The resulting cross-species are differentiated into chimera and hybrids. The definitions are summarized in Annex 1. The different possible combinations of cells or genetic material from animals and humans are presented with corresponding examples in Annex 2. A distinction should be made between intra-species and inter-species combinations. The ethical assessment of their generation will differ, depending on the species and the scale on which they are involved in the generation of cross-species and, moreover, whether the chimera or hybrids generated are intended for use in research, therapy, or, where applicable, the farm animal or companion animal sectors, and the stage to which the resulting organism should develop. The generation of such cross-species for the purposes of research and human medical therapy comes under the definition of animal experimentation and is regulated by the corresponding provisions of the Swiss animal protection legislation. However, certain applications in the farm animal and companion animal breeding sectors do not come under the definition of animal experimentation and are excluded from licensing. The regulations governing animal breeding in the Swiss Federal Act on Animal Protection and the Federal Ordinance on Animal Protection are applicable in this case.

Animal-human cross-species are particularly controversial in the context of both the scientific and public debate. This is lesser the case with animal-animal cross-species.

Hybrids and chimeras between animals which are closelyrelated within the zoological system are already known. The former include big cat hybrids between lions, tigers, jaguars and leopards and the mule and somewhat rarer hinny, which are hybrids of the horse and donkey. The best known example of a chimera cross-species is the sheep-goat chimera, which is sometimes referred to as a "geep".

The focus in the debates surrounding animal-human crosses is on ethical issues in relation to the protection and dignity of humans and, to a lesser extent, the protection and dignity of the animal. The Nationale Ethikkommission im Bereich $\mathrm{Hu}$ manmedizin (NEK) (Swiss National Advisory Commission on Biomedical Ethics) has considered the human-ethical aspects of research on human and animal embryos and foetuses and developed concrete recommendations which also cover chimeras and hybrids (NEK, 2006). The majority of the members of NEK oppose the creation of chimeras consisting of cells from humans and animals (inter-species chimeras) because an experiment could involve the formation of partial human structures within the animal organism. A minority of NEK members believe that limited authorization could be possible if it is ensured that the control of the development of the organism is not partly as-

\footnotetext{
${ }^{1}$ Members of the Ethics Committee for Animal Studies:

Prof. M. Geiser Kamber, Berne (President since 2008), Prof. A. Steiger, Berne (President until 2008), PD Dr. C. Aus der Au, Basel,

Prof. B. Baertschi, Geneva, Prof. A. Bondolfi, Lausanne (until 2008), PD Dr. A. Brenner, Basel, Prof. K. Bürki, Zurich, Prof. H. Durrer,

Oberwil (until 2008), Dr. A. Gutzwiller, Posieux, Dr. B. Heiniger, Langenthal, Prof. E. Hummler, Lausanne, Prof. S. Jakob, Berne,

Dr. K. Kuehnle, Basel, Prof. B. Lanzrein, Berne, PD Dr. B. Ledermann, Basel, Dr. M. Leuthold, Basel (until 2007), Dr. B. Matter,

Olsberg (until 2008), PD Dr. B. Riederer, Lausanne, PD Dr. K.-P. Rippe, Zurich (until 2008), Prof. B. Stadler, Bern (until 2008),

lic. iur. M. Tinner, Zurich, Dr. Th. Wannier, Fribourg.
} 
sumed by the implanted cells of humans. The majority of NEK members support the prohibition of the creation of hybrids (fusion of human and animal gametes).

\section{Biological aspects of experimentally-generated cross-species}

Experimentally-generated cross-species are divided into two categories: chimeras (cell crosses) and hybrids (genetic crosses). Two further categories are differentiated among chimeras. Primary chimeras arise through the aggregation of embryonic cells prior to organogenesis. These chimera are generally complete mixtures. Secondary chimeras are formed through cell exchange or transplantation after organogenesis. Their mixture of cells is usually limited to one or a few tissues. As annex 1 shows, examples of naturally occurring chimeras exist. These are exclusively intra-species crosses. A series of examples of experimentallygenerated interspecific crosses also exists. Some examples are established experimental models, for example transplantations of human tumour tissue to the nude mouse.

The creation of cross-species has certain biological limits. Experience has shown that primary inter-species chimera are not usually capable of development. The combination of sheep-goat embryos is an exception here. Secondary inter-species chimera can usually only be generated in host animals with naturally or induced immunoincompetence (i.e. they lack the capacity for immune defence). Inter-species hybrids can only be generated between very closely related species and are often sterile (e.g. the mule and the hinny). No genetic technology processes are used in the formation of all of the aforementioned crossspecies.

The generation of inter-species clones in the context of therapeutic cloning is also of interest in the context of the creation of cross-species. This process is not based on genetic technology. The nucleus of a cell of human origin is transferred to a denucleated animal oocyte and a cytoplasmic hybrid embryo is created. The intention here is to avoid the use of human oocytes. Initial results indicate that it is difficult to obtain cells capable of reproduction from such embryos; there may be an incompatibility between the nucleus and mitochondria. This approach may soon become obsolete, moreover, because the dedifferentiation of adult body cells to induced pluripotent stem cells (iPSCs) has been successfully carried out for mice and humans. These cells share the characteristics of embryonic stem cells. Again, chimeras, inter alia, will play an important role in the research of the therapeutic potential of these cells.

\section{Legislative provisions in the human sector}

Various countries have already passed legislation in relation to humans, which however is very different in parts. The Federal Constitution of the Swiss Confederation of 18 December 1998 stipulates that "non-human reproductive and genetic material may neither be introduced into nor combined with human reproductive material" (Article 119, paragraph 2, letter b). Fur- thermore, the St. Galler Kommentar zur Bundesverfassung ( $\mathrm{St}$ Gallen Commentary on the Federal Constitution) notes in relation to this, that "The combining of human and animal can harm not only the dignity of humanity but also the human dignity and personality of the unique individual human being. In addition to the introduction of non-human genetic material into human reproductive material, the provision also prohibits the formation of so-called inter-species hybrids (mongrels) through the fusion of the gametes of different species, and of inter-species chimeras" (Ehrenzeller et al., 2008).

The Swiss Federal Act on Reproductive Medicine (Fortpflanzungsmedizin-Gesetz, FMedG) of 18 December 1997 regulates this issue as follows (Article 36, Generation of Clones, Chimeras and Hybrids): "The generation of a clone, chimera or hybrid is punishable by imprisonment. Anyone who transfers a chimera or hybrid to a woman or animal will also be punished." The St Gallen Commentary on the Federal Constitution makes the following comments on this provision: "Article 36 of the Reproductive Medicine Act prohibits, in addition, inter-species chimeras formed from two human embryos". The following are not covered by letter b (of Article 119 paragraph 2 of the Federal Constitution) and thus only come under the reservation of the prohibition of abusive practices: i.e. the introduction of nonhuman genetic material into the somatic cells of humans; the introduction of human genetic sequences into non-human genetic material or reproductive material as occurs, for example, in the generation of transgenic animals.

The Swiss legislation is, therefore, highly restrictive and far more stringent than, for example, that of Great Britain where the generation of chimeras for research is allowed. Thus, it may be expected that the ethical and political debate on the justifiability of the generation of cross-species will continue. The extent to which standards are necessary in relation to the status of the human embryo and the protection of its dignity will have to be clarified.

However, the subject of this position statement is the effect of chimera/hybrid generation on the animal. These are legally restricted solely by the animal protection legislation.

\section{Animal protection legislation}

According to Article 4 of the Swiss Federal Act on Animal Protection (Tierschutzgesetz, TSchG) of 16 December 2005, "no person shall inflict unjustified pain, suffering or injury on an animal or cause it to experience fear or violate its dignity in any other way. The abuse, neglect or unnecessary overexertion of animals is prohibited". According to Article 10 of the Animal Protection Act "the use of natural and artificial breeding and reproduction methods in the parents or offsprings may not cause any pain, suffering, damage or behavioural disturbances resulting from or associated with the breeding aim; the provisions on animal experiments are excepted". Detailed provisions on the breeding of animals are contained in the Swiss Federal Ordinance on Animal Protection of 23 April 2008 (Tierschutzverordnung, $T S \operatorname{sch} V$ ). According to this legislation "breeding should be aimed at obtaining healthy animals which are free 
of characteristics and features that harm their dignity. Breeding aims which result in limited organ and sensory functions and deviations from species-typical behaviour are only authorized if they can be compensated by measures relating to care, keeping or feeding that do not cause distress to the animal, without intervention involving the animal and without regular medical measures. The following are prohibited: a) the breeding of animals, in which the absence or alteration of genetically determined body parts for species-typical use must be expected and as a result pain, suffering or damage is caused to the animal, and b) the breeding of animals with deviations from species-typical behaviour that could make cohabitation with members of the same species very difficult or impossible" (Article 25 Animal Protection Ordinance).

It is not inconceivable that the generation of cross-species, be it in the animal/human or animal/animal sector, could qualify as breeding that contravenes the animal protection requirements. However, the regulations require interpretation and are not linked with any clear ethical statements on the justifiable boundaries in the generation of cross-species. This concerns, in particular, the prohibition of the violation of dignity which is impaired when the distress caused to the animal cannot be justified by overriding interests (Article 3 Animal Protection Act). Thus in the case of domestic animals, livestock, wild animals and experimental animals, the substantive scope of the impairment of dignity is always determined by the balancing of interests.

If the generation of a cross-species represents a cause of distress for the animal, it may qualify for licensing as an animal experiment if the expected gain in knowledge is justified. In the case of animal experiments, animal protection law decisions on the generation of cross-species are a matter for the cantonal authorities with the participation of the supervisory and ethics committees for animal studies. Thus the latter share the ethical responsibility for the appraisal of the generation of crossspecies. Particular care should be applied in the definition of the termination criteria and the relevant current status of the ethical debate should be taken into account. Researchers are responsible for the careful monitoring of experiments and compliance with the termination criteria.

As opposed to this, the generation of cross-species outside of the context of animal experiments is not subject to official monitoring in the form of licensing. Because chimeras and hybrids are not genetically modified animals, their generation, breeding, holding, use and trade is not subject to the conditions for the licensing of genetically modified animals in accordance with Article 11 of the Animal Protection Act. The responsibility for the avoidance of harmful effects during breeding (Article 10 Animal Protection Act) primarily lies with the breeder; insofar as clear limits are not specified by other decrees, such as the Animal Protection Ordinance, or other official ordinances, the ethical assessment of breeding aims is also incumbent on breeders in the context of their individual responsibility. Their individual responsibility includes namely the legal obligation to monitor and kill. Insofar as the Animal Protection Act imposes a licensing obligation on the commercial trading of animals (Art. 13 Animal Protection Act), it should be demanded that the authorising authorities make the granting of such licenses subject to compliance with breeding regulations. These should be applied with particular care in the case of the generation of crossspecies while taking the current status of the ethical debate into account.

\section{Animal ethics considerations}

In this position statement, the Ethics Committee for Animal Studies of the SAMS and SCNAT ties in with positions that it already adopted in earlier publications. In particular, it avoids the judgemental expression "human cells" (menschliche Zellen) and uses instead the term "cells from humans" (Zellen des Menschen) based on their origin in the human body. Thus the Committee adopts the usage in accordance with its position statement "Menschliche Gene oder Menschengene?" (2002 "Humane Gene or Human Gene"). In its "Beitrag zur ethischen Beurteilung der Xenotransplantation im Hinblick auf den Schutz der Würde der Tiere" (2000), ("Contribution on the ethical assessment of xenotransplantation with regard to the protection of the dignity of animals"), the Committee had put on record that with xenotransplantation, a special form of integration of alien tissue or cells into a different species, the following main aspects must be given particular recognition: a) the best-case possible benefit (quality of life, survival period) for the organ recipient; b) the distress caused to the recipient animals by experiments in the pre-clinical phase; c) the introduction of a multitude of human genes into the genetic material of the animals and the possible consequences for the latter's well-being; d) the living conditions of the donor animals based on the health status required for the transplantation; and e) the death of many animals in itself. The criteria specified at the time are also applicable to the generation of chimeras and hybrids, irrespective of whether the organisms involved are intraspecific or interspecific chimeras or chimeras generated for research or therapy purposes. The welfare of the animal is to the fore.

In accordance with the Animal Protection Act, the following definition of the dignity of the animal is applicable to the generation of cross-species (Article 3 Animal Protection Act): "Intrinsic value of the animal which must be respected in its handling. The dignity of the animal is violated when the distress caused to the animal cannot be justified by overriding interests. Distress arises, in particular, when pain, suffering or damage is caused to the animal, it is made to experience fear or its appearance or capacities are seriously affected, or it is excessively instrumentalized".

The Ethical Principles and Guidelines for Experiments on Animals of the Swiss Academy of Medical Sciences (SAMS) and the Swiss Academy of Sciences (SCNAT) (2005) state the following in relation to genetically modified animals (paragraphs 2.6 and 4.12): "Furthermore, animals have the right to the respect of their dignity and, hence, the respect of their speciesspecific characteristics, needs and behaviours. [...] In the case of the breeding of genetically modified animals, the risk of the development of defects, suffering or pain must be particularly thoroughly evaluated". This principle must also be observed in the generation of cross-species. 
Society's concerns in relation to the generation of cross-species mainly concern the combination of an animal species with the human species. The more the human element in such combinations increases, the more it is perceived as problematic: if a gene of human origin is introduced into an animal, it is not yet "humanized". Thus, there are generally few misgivings in relation to the use of individual genes from the human organism in an animal or, conversely, the use of a therapeutically effective animal gene in the somatic genetic therapy of humans. The use of adult animal tissue in humans for therapeutic purposes, e.g. animal heart valves or the implantation of animal cells in cellular xenotransplantation, is also largely accepted. In general, it would appear that the integration of individual cells from a different species into the body of a human or an animal is accepted (microchimerism). This is not perceived as either the "humanization" of the animal in question or "animalization" of the human involved. Countless symbiotic alien organisms and even endoparasites reside permanently in every human being and animal.

The situation would appear to be different, however, when it comes to an elevated alien-species proportion, namely when structures, organ parts or organs are formed using human cells in an animal organism, when control is taken of the development of the host organism and when, in the case of transplantations into the brain, the characteristics of humans or another animal species arise in the animal. In the view of the NEK these concerns are based on the fact that the possible development by the chimera of a rudimentary form of the perception, sensibility, experience or consciousness of humans or another animal species cannot be excluded. According to the NEK, reservations in relation to the formation of organ parts or partial structures of humans in animals and in relation to interspecies chimeras in humans for research or therapeutic purposes are justified from a human ethical perspective (NEK, 2006).

In terms of animal ethics, the fundamental question arises as to whether the generation of chimeras or inter-species hybrids can be justified. The Ethics Committee for Animal Studies of the SAMS and SCNAT does not fundamentally question the generation of chimeras and hybrids in relation to the protection of the welfare and dignity of the animal, nevertheless it deems the observation of restrictive conditions as necessary for the generation of chimeras and hybrids. If the basic question regarding the generation of chimeras and hybrids is largely supported, the question arises as to whether the possibly new biological, i.e. morphological, physiological or behavioural characteristics of the new animal, could diminish its well-being and dignity. A negative impact can arise directly, for example through abnormalities, defects, illnesses and behavioural disturbances, or indirectly through the failure to sufficiently cover the biological needs in the given holding environment, for example in relation to nutrition, care, behaviour and social contact.

\section{Conclusions}

In the view of the Ethics Committee for Animal Studies of the SAMS and SCNAT, account must be taken of the following issues in relation to animal protection:
- The provisions of the animal protection legislation must be strictly observed and the issues relating to the respect of the dignity of the animal must be clarified in each individual case.

- It must be assessed with particular care whether the consequences that the introduction of numerous cells from other animal species or humans can have for the well-being of the generated animals and whether the latter's physiological and ethological needs can be adequately met.

- Termination criteria must be defined in advance for the case in which considerable abnormalities or suffering could arise in the generated animals.

- The distress caused to the generated animals as a result of experiments in the research phase, including the living conditions of the animals in respect of the health and hygiene status required for the interventions, must also be clarified.

- The generation of cross-species for the purposes of the breeding of farm animals or companion animals must be assessed on the basis of the same animal protection principles as those applied for research purposes.

\section{References}

Eidgenössisches Tierschutzgesetz vom 16. Dez. 2005; Tierschutzverordnung vom 23. April 2008: www.bvet.ch.

Ehrenzeller, B., Mastronardi, P., Schweizer, R. J., Vallender, K. A. (2008). Die schweizerische Bundesverfassung - Kommentar, 2. Auflage, Dike Verlag und Schulthess Juristische Medien (St Gallen Commentary on the Federal Constitution) (Kommentar zu Art. 119: R. Reusser und R.J. Schweizer).

Ethikkommission für Tierversuche SAMW/ SCNAT (2000). Beitrag zur ethischen Beurteilung der Xenotransplantation im Hinblick auf den Schutz der Würde der Tiere. Schweiz. Ärztezeitung 81, 36-37, und ALTEX, 17, 24-25.

Ethikkommission für Tierversuche SAMW/SCNAT, 2002 , Menschliche Gene oder Menschengene? Schweiz. Ärztezeitung 83, 236-238

NEK, Nationale Ethikkommission im Bereich Humanmedizin (2007). Ethische Aspekte bei der Forschung an menschlichen Embryonen und Foeten, www.nek-cne.ch.

Swiss Academy of Medical Sciences (SAMS), Swiss Academy of Sciences (SCNAT) (2005). Ethical Principles and Guidelines for Experiments on Animals, $3^{\text {rd }}$ edition (www.samw. ch)

\section{Correspondence to}

Prof. Dr. phil. nat. Marianne Geiser Kamber

Institut für Anatomie der Universität Bern

Baltzerstrasse 2

3000 Bern 9

Switzerland

e-mail: geiser@ana.unibe.ch 


\section{Annex 1: Definition of Chimeras and Hybrids}

Chimeras: mixtures of cells, cross-species. Organisms composed of cells of different embryonic origin. A distinction is made between intra-species chimeras (cells from the same species) and inter-species chimeras (cells from different species).

Primary chimeras: mixtures of cells which arise through the combination of two embryos or one embryo with embryonic stem cells prior to organogenesis. As a rule, all of the organs are chimerous in primary chimeras (including the germline).

Secondary chimeras: mixtures of cells or tissues that arise after organogenesis. As a rule, in secondary chimeras the chimerism is limited to individual organs or tissues. Organisms generated after organ transplantation belong to this category (see also microchimerism).

Microchimerism: individual cells which can be found after organ transplantation in tissues other than the transplant.

Genetic hybrids: 1:1 genetic mixes which arise through crossing. Usually intra-species, also inter-species in closely-related species (e.g. horse-donkey: mule and ninny).

Cytoplasmic-nuclear hybrids: arise through the transplantation of a nucleus in an oocyte of the same or a different species (clones).

\section{Annex 2: Overview of chimeras and hybrids}

E: Embryo (before organogenesis) or Embryonic Stem Cells (ES Cells) or equivalent (induced pluripotent stem cells, iPSCs);

A: Adult cells or tissue (after organogenesis);

italics: examples

\begin{tabular}{|c|c|c|}
\hline & Intra-species & Inter-species \\
\hline $\begin{array}{l}\text { Primary Chimeras } \\
\text { En E }\end{array}$ & $\begin{array}{l}\text { Animal n Animal } \\
\text { Mouse Aggregations or ES Cell Chimeras } \\
\text { Human n Human } \\
\text { (Spontaneous Chimeras) }\end{array}$ & $\begin{array}{l}\text { Animal n Animal } \\
\text { Sheep-Goat Chimeras (Geeps) } \\
\text { Animal n Human }\end{array}$ \\
\hline $\begin{array}{l}\text { Secondary Chimeras } \\
\text { Ẹ A }\end{array}$ & $\begin{array}{l}\text { Animal Animal } \\
\text { Teratoma-Induction } \\
\text { ES Cell Therapy Models } \\
\text { Human Human } \\
\text { ES Cell Therapy }\end{array}$ & $\begin{array}{l}\text { Animal Animal } \\
\text { Therapy Models } \\
\text { Human Animal } \\
\text { Therapy Models } \\
\text { Animal Human }\end{array}$ \\
\hline $\begin{array}{l}\text { Secondary Chimeras } \\
\text { A A }\end{array}$ & $\begin{array}{l}\text { Animal Animal } \\
\text { Organ/Cell Transplants } \\
\text { Bone Marrow Transplants } \\
\text { Freemartins (spontaneous) } \\
\text { Human Human } \\
\text { Organ Transplants incl. Fœtal Cells } \\
\text { Bone Marrow Transplants } \\
\text { Embryo/Foetus-Mother Chimerism }\end{array}$ & $\begin{array}{l}\text { Animal Animal } \\
\text { Xenotransplantation Models } \\
\text { Human Animal } \\
\text { HuSCID Mouse } \\
\text { Tumour transplantation in Nude Mouse } \\
\text { Animal Human } \\
\text { Xenotransplantation }\end{array}$ \\
\hline $\begin{array}{l}\text { Genetic Hybrids } \\
\delta \mathbf{x}+\end{array}$ & $\begin{array}{l}\text { Animal x Animal } \\
\text { Hybrid Mice }\end{array}$ & $\begin{array}{l}\text { Animal x Animal } \\
\text { Mule, Ninny } \\
\text { Humaṇ Animal }\end{array}$ \\
\hline $\begin{array}{l}\text { Cytoplasmic-Nuclear Hybrids } \\
\text { Nucleuș Cytoplasma }\end{array}$ & $\begin{array}{l}\text { Animal Animal } \\
\text { Clones }\end{array}$ & $\begin{array}{l}\text { Human Sperm in Hamster-Oocytes } \\
\text { Human Animal } \\
\text { Interspecies clones: Human nucleus in } \\
\text { animal-Oocyte for harvesting of ES Cells }\end{array}$ \\
\hline
\end{tabular}

